\title{
Climate change and management literacy: the case of the Niger Delta universities in Nigeria
}

\author{
Maureen N Koko and Barineme B Fakae \\ Rivers State University of Science and Technology, Nkpolu-Oroworukwo, Port Harcourt, \\ Rivers State, Nigeria \\ E-mail: koko.maureen@ust.edu.ng, bbfakae@ust.edu.ng
}

\begin{abstract}
The need for adequate knowledge of climate change and its management in the present day volatile and hazardous environment cannot be over-emphasized. Researchers have warned that environmental changes that emanate from increasing temperature which leads to health related issues, emission from ozone layers, land degradation, etc., require adequate environmental techniques if our socio-economic, political and cultural lives are to be preserved. This study therefore examined the literacy levels of university management in climate change in order to establish if there are clearly specified environmental management policies guiding their activities and suggest possible empowerment strategies for better management of climate change in the educational sectors. To achieve the goals of the study, an instrument titled "Niger Delta Universities Climate Change Inventory (NDUCCl) was utilized to gather the relevant data for analyses. Results of the findings indicate that the literacy level of a large number of management staff in the study is restricted to the traditional description of climate change as basically administrative changes within the university that causes instability. It was also found that a high percentage of respondents indicated that there are no clearly specified environmental policies in the universities that guide the management of climate change.
\end{abstract}

Keywords: Climate Change; Literacy; Management; Universities; Niger Delta and Nigeria.

\section{INTRODUCTION}

Recent concerns by scientists and environmentalists focus on the effect of global warming on our environment. Fritjof Capra (2010) in his article, The New Facts of Life, warned that in the coming decades, the survival of humanity will depend on our ecological literacy i.e. our ability to understand the basic principles of ecology and to live accordingly. This input suggests the importance of the need for awareness and knowledge in observing and understanding the environment we live in. Concerned citizens therefore warn that burning greenhouse gases could have irreversible damaging effects on ozone layer and contribute to warming the earth's atmosphere and thus, pollute our living environment. In fact, Osamuna (2010: 19) alerted that "since most environmental impacts are the cumulative result of many human activities, most environmental actions must be taken at the national or even local levels. Hence, the need for the present study which seeks to examine the implications of the raised concerns to the educational manager in the Niger Delta.
The turbulent nature of the once serene and hospitable Niger Delta environment comprising chore five states in Nigeria raises palpable concerns. Before the oil boom, in the early seventies, the Niger Delta communities were known for serene environment, devoid of diverse climatic influences. The people of the region that once enjoyed relative peace and clear stability, suddenly the observed changes that brought about militancy, kidnappings, communal wars and the likes. The argument is that the trend is influenced by the struggle for one resource control, wealth sharing, leadership contests, etc. The resultant effect is that our once quiet learning environments (primary, secondary and tertiary institutions) have also been immersed with secret cults, trade unionism, protests, power struggle, etc. Thus, effective management which can breed cordiality becomes a herculean tasks for the leaders. Pathetically, one wonders the implication of the painted scenario to the university leadership.

The fact that our climate is changing cannot be overemphasized with the observation that the planet is warming faster than expected. Such climate 
changes that are sometimes influenced by human activities or societal problems inevitably make governance very difficult. Thus, these concerns have indeed prompted concerted discussions at different forum which recognized the shortfalls in policymakers' scientific knowledge regarding environmental changes that can hamper effective management of an organization.

A few years back, issues that border on the environment were left for the experts in environmental sciences, engineering and sciences. But the realities are before us pointing to the need for administrators to be armed on how to combat the impact of pollution, gas and oil emissions (Mamman 2010) and environmental degradation on our environment and school environment in particular. It is common knowledge that whatever impacts the communities, affect the educational environments within the vicinity. For example, the effect of Tsunami in most Asian countries some years ago had devastating effect on the learning environment such that no school activities took place while the scourge was on. The recent erosion and flooding in many parts of Nigeria also had a terrible effect on the affected communities making teaching and learning, staff and students management tasking.

Although observation shows that while a lot of studies are embarked upon by scientists to control the effect of climate change in developed countries such as the United States of America, Britain, Japan, etc., little attention has been given to this all important aspect of life in Nigeria's educational sectors in particular. Worst still, not much have been done in the area of preparing educational managers to effectively make decisions that can lead to the effective management of their environment. Yet, Capra (2010), emphatically warn that "we need to teach our children, our students, and our corporate and political leaders, the fundamental facts of life - that one species' waste is another species' food; ...". To what extent can this exercise be achieved without the establishment of the knowledge base of university management on climate change in the Niger Delta region? Osamuna (2010:17) posits that knowledge of the public perception on environmental change is important for several reasons. Majorly amongst the reasons, "as a measure of the effectiveness of official communication about the topic and an indication of the potential for change in behavior to address the problem".
The outlined facts form the bedrock of the present study and seek to examine and provide information on the knowledge level of university leaders in climate change; establish whether there are clearly specified environmental policies guiding climate change in universities; and highlight the road map to empower university management to effectively manage the changing climate in the environment. This study therefore, will address the outlined concerns through the results of the analyzed data.

\section{WHAT IS CLIMATE CHANGE IN THE CONTEXT OF EDUCATIONAL MANAGEMENT IN THE NIGER DELTA UNIVERSITIES?}

The Niger Delta region is located in what is popularly known as the South-South geo-political zone of the Federal Republic of Nigeria. It is made up of nine (9) states namely, Abia, Akwa Ibom, Bayelsa, Cross River, Delta, Edo, Imo, Ondo and Rivers States. However, as a result of the level of oil explorations and revenue, Akwa Ibom, Bayelsa, Delta, Ondo and Rivers states are generally recognized as core oil producing states and thus represent core Niger Delta. Unfortunately, as a result of the revenue base of these states and the quest for resource control by the citizenry, the environment has been characterized by militancy and diverse communal wars, making the environment volatile, to some extent for human habitation.

There are nine federal and state universities in the five core states and a total of 16 universities in the nine states of the Niger Delta region. Pathetically, these universities experience turbulence from time to time as a result of disagreements between different units of management or between management and their employees. However, experience shows that when this happens, it becomes expedient to identify the remote causes of such occurrence in order to effectively manage the situation before it escalates to an alarming proportion.

The fact that environmentalists have cautioned that we must protect the environment so as to have a better future makes a clear understanding of what climate change stands for more essential. Over the years, discussions on climate change has centered on the coming together of physicists, biologists, geologists, and other environmentalists without the involvement of other experts in management or organizational leadership. Yet, Capra (2010) and Wikipedia (2010) uphold that ecological literacy or environmental education should be the most 
important part of education at all levels. In other words, educational leadership at all levels, and Nigerian universities in particular must make frantic efforts to understand what climate change stands for in order to effectively apply its management rules.

However, experience shows that climate change may mean different things to different people. For example, for a non-scientist, climate change may mean just the changes in the observed weather in a given environment. It can also mean the changes in our room temperature which can be measured with a thermometer or changes in our body temperature (sometimes ascribed to fever) which one may assume resulted from changes of the climate. Likewise, climate change can be described as the changes in nature. For an educationist, climate change may be understood to mean the observed changes in the climate of the classroom or school (Koko, 2002). These are changes that may result from internal or external governance structure, student/staff management that are contestable by stakeholders. For a layman, the outlined descriptions may be acceptable meanings of climate change. In the context of this study, an attempt is made here to actually highlight the meaning of climate change in the context of educational management.

Climate change according to Wikipedia (2010), is a long-term change in the statistical distribution of weather patterns over periods of time that range from decades to millions of years. It also means a change in the average weather conditions. In the context of environmental policy, climate change usually refers to changes in modern climate which may be limited to a specific region. The United Nations Framework Convention on Climate Change cited in Wikipedia (2010), defines the concept as "a change of climate which is attributed directly or indirectly to human activity that alters the composition of the global atmosphere and which is in addition to natural climate variability observed over comparable time periods." The United Nations definition of climate change is so apt to the present study which acknowledges that the climate change phenomenon can be human induced. For instance, the cases of emissions from bush burning, fossil fuel combustion from oil exploration and exploitation, ozone depletion, etc., are facilitated by human beings. In fact, scientists have warned that human activities such as burning greenhouse gases in particular could have irreversible, damaging effects on ozone layer and contribute to warming the earth's atmosphere.
From an educational management point of view, climate change is understood as the changes in the general feel and atmosphere of the school organization. According to Hoy and Miskel (2008:198), "school organizational climate is a relatively enduring quality of the school environment that is experienced by participants, affects their behavior, and is based on their collective perceptions of behavior in schools". In other words, changes that occur in the personality of the school organization can be described as climate change of the school. When a school which has been identified as "zero turbulence" environment, suddenly experiences uncontrollable crisis, it can be deduced that the organization is experiencing obvious climate change which is influenced by human activities. It has been found that the atmosphere of a school has serious impact on its members - changes in leadership, system structure, membership, etc., to some extent; affect the behavior of members of the school (Koko, 2005; Hoy \& Miskel, 2008), and can lead to what can be perceived as school climate change. According to Albert (2010) the intense heat experienced by Nigerians, the increased flooding of Niger Delta communities and the problems faced by air travelers due to bad weather have all shown that the problem of climate change is a monster with a multiplicity of dimensions. To buttress this point, Okeke (2010) opined that climate change which results to weather conditions sometimes have controlling impact on human activities and endeavours.

However, since the perception of scientists and environmentalists on the meaning of climate change differ from that of administrators, it became pertinent to clearly examine the individual perceptions of Niger Delta universities' leadership in this study in order to establish their actual literacy level of climate change. This attempt became necessary in order to establish the existence of specified environmental policies guiding management of climate change in the sample universities; this invariably will expose the need to consciously guide the respondents on ways to effectively manage their environment in order to achieve set goals.

\section{METHODS}

The study adopted a descriptive survey design using a randomly selected sample of 105 university leaders comprising Vice Chancellors, Deputy Vice Chancellors, Deans/Directors of Faculties/Institutes, Heads of Department and Senior Administrative officers in five Universities in the five core Niger Delta 
States of Nigeria. A self-designed instrument titled "Niger Delta Universities Climate Change Inventory (NDUCCl)", containing eight (8) multiple and openended questions were used to collect data for analyses. The simple descriptive statistics of frequency counts, percentages, and independent means were used to analyze the collected data. For the interpretation of results, mean scores of 3.50 and above for research question 1, 2.00 and above for research question 3 and a high percentage of 50 and above were used as the acceptance parameter for the analysed results.

\section{RESULTS}

Table 1 indicates percentage and mean scores of respondents' level of knowledge on climate change in the universities as; global warming as a result of emissions (66.6\%/mean 4.67); sudden instability in a stable school environment (76\%/mean 5.06); and changes in management structure that brings conflict in a school (85.7\%/mean 6.00). Pollution that changes the air of the environment, smokes from bush burning that changes the weather, change in the weather, were all rejected while sunshine during rainy season was not recognized as factor in climate change.

Table 2 shows that sixty eight per cent (68\%) of the respondents indicated there are no clearly specified environmental policies on Climate Change to guide management in the respective universities, twenty seven per cent $(27 \%)$ stated that there are such policies while five per cent $(5 \%)$ are not sure.

Table 3 shows that out of the four (4) identified possible strategies, three (3) were accepted as possible empowerment tools for the management of climate change in the Niger Delta universities. The mean and percentage ratings were; (71\%/mean 2.86) for general handbook on climate change management; training through seminars/workshop (69\%/mean 2.74); followed by enlightenment and sensitization on Climate Change (50\%/mean 2.02). Enhancement of organizational effectiveness though identified as a possible strategy was rejected by the respondents with 9.5\%/0.38 mean scores.

Table 1: Mean and Percentage scores on the Literacy level of University Leadership on Climate Change: $\mathrm{N}=105$.

\begin{tabular}{|c|c|c|c|c|c|}
\hline S/No & Climate Change Descriptions & Scores & $\%$ & Mean & Decisions \\
\hline 1 & Change in the weather & 50 & 47.6 & 3.33 & Rejected \\
\hline 2 & Sunshine during rainy season & 0 & 0.0 & 00 & Rejected \\
\hline 3 & $\begin{array}{l}\text { Global warming as a result of gas } \\
\text { emissions }\end{array}$ & 70 & 66.6 & 4.67 & Accepted \\
\hline 4 & $\begin{array}{l}\text { Pollution that changes the air of the } \\
\text { environment }\end{array}$ & 50 & 47.6 & 3.33 & Rejected \\
\hline 5 & $\begin{array}{l}\text { Smokes from bush that changes the } \\
\text { weather }\end{array}$ & 50 & 47.6 & 3.33 & Rejected \\
\hline 6 & $\begin{array}{l}\text { Sudden instability in a stable school } \\
\text { environment }\end{array}$ & 80 & 76.0 & 5.06 & Accepted \\
\hline 7 & $\begin{array}{l}\text { Changes in management structure that } \\
\text { brings conflict in a school }\end{array}$ & 90 & 85.7 & 6.00 & Accepted \\
\hline
\end{tabular}

Table 2: Percentage Scores on Environmental Policy on Climate change: $\mathbf{N}=105$.

\begin{tabular}{|c|l|c|c|c|}
\hline S/No & \multicolumn{1}{|c|}{ Question } & Yes & No & \\
& \multicolumn{1}{|c|}{ Not Sure } \\
& Are there clearly specified environmental & $(28)$ & $(72)$ & $(5)$ \\
& policies guiding Climate Change in your & $27 \%$ & $68 \%$ & $5 \%$ \\
\hline
\end{tabular}


Am. J. Sci. Ind. Res., 2011, 2(5): 820-826

Table 3: Mean and Percentage Responses on Possible Empowerment Strategies to manage Climate Change.

\begin{tabular}{|c|c|c|c|c|c|}
\hline S/No & $\begin{array}{c}\text { Possible Empowerment Strategies on } \\
\text { Climate Change }\end{array}$ & Scores & $\%$ & Mean & Decisions \\
\hline 1 & Enlightenment on Climate Change & 53 & 50 & 2.02 & Accepted \\
\hline 2 & Training through Seminars / Workshops & 72 & 69 & 2.74 & Accepted \\
\hline 3 & $\begin{array}{l}\text { Enhancement of Organisational } \\
\text { Effectiveness }\end{array}$ & 10 & 9.5 & 0.38 & Rejected \\
\hline 4 & $\begin{array}{l}\text { General Handbook on Climate Change } \\
\text { Management }\end{array}$ & 75 & 71 & 2.86 & Accepted \\
\hline
\end{tabular}

\section{DISCUSSION OF FINDINGS}

Climate change has recently become extremely topical. No day passes without the issue of climate change being exhaustively discussed either in print, media or in different conferences and seminars such that the non-initiated begins to wonder its importance to the populace. These concerns however formed the main objective of this study which attempted to establish the climate change literacy levels of university leadership in order to find out if their knowledge were based on existing environmental policies within the organization and to test some identified strategies that may empower them to effectively manage their environment.

The results on Table 1 revealed that university management in the study subscribed to the fact that Climate Change in universities connotes, (1) changes in the management structure that brings conflict in the system with approximately 86\%/6.00 mean scores; (2) sudden instability in a stable school environment 76\%/5.06 mean scores, and (3) global warming as a result of gas emissions $67 \% / 4.67$ mean scores. This result is not surprising because of the composition of the sample which is made up of a mixed-grid of academic and nonacademic management staff whose orientation is not restricted to the office or classroom environment. Other items such as change in the weather; sunshine during raining season; pollution that changes the air of the environment and smokes that changes the weather were not accepted as possible climate change indices.

In line with the inputs of many researchers it is argued that one way of viewing the climate of the school is its organizational health (Hoy, Tarter \&
Kottkamp, 1991; Hoy \& Miskel, 2008),). Hoy \& Miskel (2008:203), posits that a healthy school organization is one in which the technical, managerial and institutional levels are in harmony. Such an organization is both meeting its needs and successfully coping with disruptive outside forces as it directs its energies toward its mission. However, it is conceived that when the reverse is the case, there is possible change in the climate of the institution. Perhaps, in the case of the studied institutions, this may be the influencing factor for the observed findings.

Also, the respondents in this study which is made up of fewer environmentalists and more of administrators with restricted knowledge of globally acknowledged definition of climate change, may to some extent, influence the higher percentage ascribed to the items in research question one. Nevertheless, this observation projects the suggestion by Stone (2009), that as a result of environmental challenges which includes climate change, ecological literacy is of prime importance for all. In support, Capra (2010) posits that eco-literacy must be a critical skill for business leaders and professionals and should be the most important part of education at all levels.

In other to establish further the reason for the outlined findings in Table 1, the researchers asked whether there are clearly specified environmental policies in the sampled universities which can help the leadership manage their environment better. The result indicated that a large number, (68\%) subscribed to the fact that there are no such policies. Twenty seven per cent (27\%) agreed that 
there are such policies while five per cent (5\%) were not sure.

This result was expected since it has become clear that most university management in the Niger Delta region were not particularly conversant with the true meaning of climate change from the environmentalists point of view but rather alluded to the educational management description of the concept. This may have been influenced by the non inclusion of a clear specification on climate change management procedures by the researchers in the present instrument. However, literature has it that climate change has to do with environmental changes that result from diverse phenomenon such as long-term change in the statistical distribution of weather patterns over periods of time, or global warming, (Wikipedia 2010); a change of climate which is attributed directly or indirectly to human activity that alters the composition of the global atmosphere and in addition to natural climate variability observed over comparable time periods (UN as cited in Wikipedia, 2010); and also changes in the general feel and atmosphere of the school organization (Hoy \& Miskel, 2008).

Researchers have pointed out the level of deterioration of the physical environment of our communities, particular the Niger Delta where so much economic activity and the people's livelihood depend. The observation that through gas flaring and oil exploration, health and other related issues arising from pollution of the environment becomes imminent makes the empowerment of the citizenry essential (Osamuna 2010).

Results on table 3 highlighted the suggested empowerment strategies in management of climate change in universities. The respondents indicated the need for a general handbook on climate change $(71 \% / 2.86)$ and that concerted training through workshops/seminars and motivational talks $(69 \% / 2.74)$ as well as rigorous enlightenment or sensitization activities (50\%/2.02), as one of the means of encouraging better understanding and effective management of climate change by the university leadership in the Niger Delta.

This finding is totally in line with the contributions of Stone (2009), Capra (2008), and Wikipedia (2010) who in their different write-ups recommended the importance of training everyone in environmental education in order to arm them with skills to effectively manage the environment since according to Capra "the survival of humanity will depend on our ecological literacy". Murlis \& Davies (2001) as cited in Osamuna (2010) were of the opinion that works focused on environmental or climate change were carried out to obtain more rounded understanding of public attitudes towards the environment. Specifically, Osumanu (2010) in support stated that "in West Africa, re-awakening in thinking is crucial, as it is likely to bring about lasting and sustainable development in the region".

In our present day tumultuous society, it has become very expedient for everyone to be armed to effectively manage the obvious changes that emanate from different factors in our environments. Experience shows that it is no longer exciting for qualified and astute academic and administrators to aspire and compete for management positions in the Niger Delta region as a result of the expected criminalities and conflicts by unscrupulous elements within the systems. Kidnappings for ransom and revenge are becoming the order of the day and highly placed officers are at risk. Recently, a newly appointed Vice Chancellor's spouse was kidnapped and a huge ransom requested from the family. The kidnap according to sources was a protest by some colleagues within the system who claim that the incumbent does not deserve the appointment.

\section{CONCLUSION}

Leadership at the university level bestows on the incumbent arduous responsibilities with high expectations from internal and external forces. Despite all these, the university leadership is equally expected to effectively manage the environment so that teaching and learning can take place. Unfortunately, most universities in Nigeria and especially in the Niger Delta have in recent times experienced incessant instability as a result of strikes, disharmony within the system and disaffection between the leadership and workers on one hand, and the students on the other hand which can be likened to changes in climate of the environment.

This study has clearly shown the level of ignorance exhibited by respondents in the study on the concept of climate change which is one determining factor in social, economic and political life of the university environment. Universities all over the world can only thrive in an environment devoid of crisis and instability. It is therefore expected that the leadership should be conversant with the best 
approach to handle such menace for peace to be restored. Thus, it is absolutely urgent that all members of the university communities be adequately prepared and equipped to face the obvious challenges of climate change. As a result, adequate information on the impact of climate change on our environment, economy and health will suffice in order to encourage better environmental management.

Since this study has revealed lack of clear climate change management policies in the universities in the study, conscious efforts should be made to review existing university laws in order to incorporate this very important management principle. The reviewed university laws must make provisions on adequate sensitization and training of all employees in the management of climate change.

Finally, the negative effects of climate change are with us and therefore all stakeholders in the educational industries must be prepared to contend with the challenge. The age-long belief that universities are peculiar from other sectors of the economy has been overtaken by the realities of the day and therefore it is time to examine new paradigms of managing the system for tranquility.

\section{REFERENCES.}

Albert, I.O. (2010). Climate Change and Conflict Management in Nigeria. A Paper presented at the Law and Climate Change in Nigeria Workshop. Faculty of Law, University of Ilorin, $13^{\text {th }}-14^{\text {th }}$ May.

Capra, Fritjof (2010). The New Facts of Life. Retrieved 10/24/2010 http://www.ecoliteracy. or/essays/newfacts-life.

Hoy, W.K. \& C.G. Miskel (2008). Educational Administration; Theory, Research and Practice. New York: McGraw-Hill Higher Education.
Hoy, W.K., Tarter, C.J. \& Kottkamp, R. (1991). Open Schools/Healthy Schools: Measuring Organizational Climate. Beverly Hills, CA: Sage.

Koko, M.N. (2002). Organizational Behaviour: Concepts and Dimension. Port Harcourt: Bengray Publishers.

Koko, M.N. (2005). Human Management: A Practical Approach. Port Harcourt: Harey Publishers Co.

Mamman, F.N. (2010). Teacher's and Student's Perception of Climate Change on Teaching and Learning Process: A Case Study of University of Abuja. A Paper presented at the 2010 NAEAP International Conference. Port Harcourt, 26 - 29 October.

Okeke, B.S. (2010). Environmental Pollution and Climate Change : The Implications for Classroom Management. A Lead Paper presented at the 2010 International Conference of NAEAP on Educational Management, Environmental Literacy and Climate Change. Port Harcourt, 26 - 29 October.

Omoregie, E.O. (2010). Empowering School Heads for Effective Management of Climate Change in Edo State. A Paper presented at the 2010 International Conference of NAEAP on Educational Management, Environmental Literacy and Climate Change. Port Harcourt, 26-29 October.

Osanusa, I.K. (2010). Propagation and Management of Environmental Change in West Africa. A Lead Paper presented at the 2010 International Conference of NAEAP on Educational Management, Environmental Literacy and Climate Change. Port Harcourt, 26 - 29 October.

Stone, M.K./Centre for Ecoliteracy (2009). Smart by Nature: Schooling for Sustainability. Centre for Ecoliteracy: Watershed Media.

Wikipedia, the free encyclopedia (2010). Climate Change. Retrieved 10/24/2010. http://en.wikipedia.org/wiki/Climate_change.

Wikipedia, the free encyclopedia (2010). Ecological Literacy. Retrieved 10/24/2010. http://en.wikipedia.org/wiki/Ecological_literacy. 